\title{
William Grant Craib, M.A.
}

Professor William Grant Craib, who died on September I, I933, was born at Banff on March IO, I882. His death occurred after a few hours' illness, at Kew, where he had been spending part of his long vacation working in the Herbarium on the Siamese flora.

Craib received his early education at Banff and Fordyce Academies, and later entered Aberdeen University, taking the degree of M.A. in 1907. In 1908 he received a temporary appointment as Acting Curator of the Herbarium at the Royal Botanic Gardens, Calcutta. While in India he made large collections of plants from the North Cachar Hills, which he subsequently named. In I909 he accepted the post of Assistant for India at Kew. At this time large consignments of Siamese plants were being received, and Craib's interest was roused in the flora of that area.

From I9I I onwards he published, under the title Contributions to the Flora of Siam, descriptions of numerous species. In 1925 he commenced the publication of what must be considered his principal work, his Flora Siamensis Enumeratio, and at the time of his death the first volume had been issued as well as the first part of Volume II. The manuscript of the second part of Volume II had also been sent to press.

During his undergraduate days Craib had shown his interest in the plants around Banff, and in 1912 he published the Flora of Banffshire, a list of flowering plants and ferns with their local distribution.

In 1915, on the invitation of Bayley Balfour, he became Lecturer in Forest Botany and Indian Trees in the University of Edinburgh, and while holding this post he published a series of papers on the Regional Spread of Moisture in the Wood of Trees.

While in Edinburgh in I9I 7 he married Mary Beatrice, daughter of the late Mr James Turner of Acton. Mrs Craib entered whole-heartedly into his work and was able to assist him in many ways.

He was elected a Fellow of the Royal Society of Edinburgh in 1920, and during the same year became a Fellow of the Linnean Society.

In 1920 he was appointed to the Regius Professorship of Botany at Aberdeen. Here he entered enthusiastically into the work of teaching and research. He devoted himself largely to Systematic Botany, and encouraged special research in the subject among his students, several 
of whom have made contributions to the flora of Siam. Unfortunately a serious accident in $192 \mathrm{I}$, which resulted in the loss of a leg, prevented an active life.

Professor Craib was a stimulating teacher, and was able to inspire his students with some of his own enthusiasm. His botanical colleagues have lost a distinguished systematist who was always willing to give help and valuable advice.

M. W. 